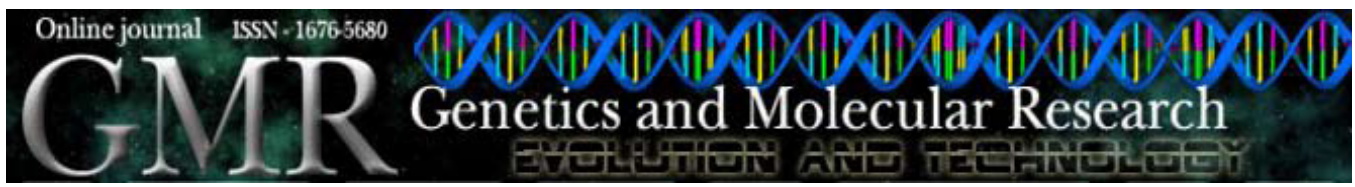

\title{
Cytogenetic comparison of tree frogs of the genus Aplastodiscus and the Hypsiboas faber group (Anura, Hylidae)
}

\author{
K.A. Carvalho ${ }^{1}$, P.C.A. Garcia ${ }^{2}$ and S.M. Recco-Pimentel ${ }^{1}$ \\ ${ }^{1}$ Departamento de Anatomia, Biologia Celular e Fisiologia e Biofísica, \\ Instituto de Biologia, Universidade Estadual de Campinas, Campinas, SP, Brasil \\ ${ }^{2}$ Departamento de Zoologia, Instituto de Ciências Biológicas, \\ Universidade Federal de Minas Gerais, Belo Horizonte, MG, Brasil \\ Corresponding author: S.M. Recco-Pimentel \\ E-mail: shirlei@unicamp.br
}

Genet. Mol. Res. 8 (4): 1498-1508 (2009)

Received September 22, 2009

Accepted October 13, 2009

Published December 18, 2009

\begin{abstract}
Four species of Aplastodiscus and two species of Hypsiboas were cytogenetically compared. Aplastodiscus perviridis, A. cochranae, $H$. albomarginaus, and $H$. faber had $2 \mathrm{n}=24$ chromosomes, while $A$. albosignatus and A. leucopygius had $2 \mathrm{n}=20$ and $2 \mathrm{n}=18$ chromosomes, respectively. Aplastodiscus perviridis and A. cochranae had identical karyotypes, as indicated by their chromosomal morphology, the location of the nucleolus organizer region (NOR) on chromosome pair 12, and the heterochromatin pattern. The NOR-bearing chromosomes of $A$. albosignatus and A. leucopygius (pair 9) were very similar in size and morphology (metacentric) when compared to A. perviridis and A. cochranae (pair 12) and to H. faber (pair 11); the NOR of these chromosomes also occurred in the same region, suggesting that these chromosomes are homologous. Although H. albomarginatus differs from the other species with regard to the location of its NOR on pair 2, this species had the same diploid number and a chromosomal morphology similar to that of A. perviridis and A. cochranae. Chromosomal differentiation among the species appears to have occurred by reduction in chromosome number.
\end{abstract}

Key words: Aplastodiscus; Hypsiboas; Karyotype; Nucleolus organizer region 


\section{INTRODUCTION}

The genus Aplastodiscus A. Lutz in B. Lutz (1950) currently consists of 15 species: A. albofrenatus (Lutz, 1924), A. albosignatus (Lutz and Lutz, 1938), A. arildae (Cruz and Peixoto, 1985), A. callipygius (Cruz and Peixoto, 1985), A. cavicola (Cruz and Peixoto, 1985), A. cochranae (Mertens, 1952), A. ehrhardti (Muller, 1924), A. eugenioi (Carvalho e Silva and Carvalho e Silva, 2005), A. flumineus (Cruz and Peixoto, 1985), A. ibirapitanga (Cruz and Peixoto, 1985), A. leucopygius (Cruz and Peixoto, 1985), A. musicus (Lutz, 1949), A. perviridis (Lutz and Lutz, 1950), A. sibilatus (Cruz et al., 2003) and A. weygoldti (Cruz and Peixoto, 1987) (for review, see Faivovich et al., 2005; Frost, 2009). However, until the systematic revision of the Hylidae by Faivovich et al. (2005), this genus had only two species, $A$. perviridis A. Lutz in B. Lutz (1950) and A. cochranae (Mertens, 1952). Aplastodiscus perviridis occurs from central and southeastern Brazil to northeastern Argentina (Cei and Roig, 1961; Frost, 2009), while A. cochranae occurs at only three locations in the State of Santa Catarina, Brazil (Garcia et al., 2001).

The genus Aplastodiscus was initially separated from the genus Hyla Laurenti (1768) because of differences in finger and toe structure (A. Lutz in B. Lutz, 1950). However, since there are close morphological similarities between these two genera, some authors have doubted the validity of this separation, and subsequent publications continued to use the name Hyla perviridis instead of A. perviridis (Bokermann, 1967; Bokermann and Sazima, 1973; Cardoso et al., 1989; Cardoso and Haddad, 1992). The species A. cochranae was described as Hyla cochranae Mertens (1952), but Bokermann (1966) considered it synonymous to Aplastodiscus perviridis, a proposal accepted by various authors (Lutz, 1973; Duellman, 1977; Cei, 1980; Frost, 1985; Lavilla, 1992). Garcia et al. (2001) validated A. cochranae based on external morphology.

According to Lutz (1950), the species Hypsiboas albosignatus (previously referred to as Hyla albosignata) is the closest to A. perviridis because of its size, color and song. Bokermann (1967) also reported similar song patterns for $A$. perviridis, A. albofrenatus (previously Hyla albofrenata) and $A$. albosignatus (previously Hyla albosignata). Another characteristic that approximates these species is the development of metacarpal and metatarsal tubercles, which could be related to the habit of digging burrows in mud (Garcia et al., 2001). A morphological phylogenetic analysis of the genus Hyla that included Aplastodiscus has corroborated the close relationship among these species (Silva, 1998).

Haddad et al. (2005) reported that $A$. perviridis had the same rare reproductive behavior, which is specific to species of the A. albofrenatus and A. albosignatus groups (referred to by Haddad as the Hyla albofrenata and H. albosignata complexes). Based on this similarity, these authors suggested a monophyletic origin for Aplastodiscus and these Hyla complexes.

Faivovich et al. (2005) provided a systematic review of the Hylidae based on molecular data. In this review, Brazilian species previously included in the "albosignata" and "albofrenata" complexes of the Hyla albomarginata group were transferred to the genus Aplastodiscus. In addition, the two species of the "albomarginata" complex of Hyla, e.g., Hyla albomarginata, were included in the Hypsiboas faber group. According to these authors, the genera Aplastodiscus and Hypsiboas are members of the tribe Cophomantini of Hylinae.

There have been few cytogenetic studies of Aplastodiscus and of the species of the Hypsiboas faber group, with most of the karyotypes having been described using conventional techniques. Bogart (1973) found a distinct chromosome number for A. albofrenatus (Tijuca, RJ, $2 \mathrm{n}=24$ and Boracéia, SP, $2 \mathrm{n}=22$ ) and A. albosignatus (Boracéia, SP, $2 \mathrm{n}=20$ and Teresópolis, RJ, $2 \mathrm{n}=18$ ). In the Hypsiboas faber group, only the karyotype of $\mathrm{H}$. albomarginatus $(2 \mathrm{n}=24)$ (Beçak, 1968; Gruber et al., 2007) has been described. 
In the present study, four species of Aplastodiscus representing the A.perviridis group (A. perviridis and A. cochranae) and the A. albosignatus group (A. albosignatus and A. leucopygius) and two species currently included in the $H$. faber group (H. albomarginatus and $H$. faber) were analyzed cytogenetically in order to assess the relationship between $A$. perviridis and A. cochranae, and between Aplastodiscus and the species of the H. faber group.

\section{MATERIAL AND METHODS}

The collection sites and the number of specimens analyzed are shown in Table 1. Permissions for collecting the specimens were issued by the Instituto Brasileiro do Meio Ambiente e dos Recursos Naturais Renováveis (IBAMA - Proc. No. 02001.008867/01-92). All voucher specimens were deposited in the Célio Fernando Baptista Hadadd (CFBH) Collection, in the Department of Zoology of the State University of São Paulo (UNESP), Rio Claro, SP, Brazil.

\begin{tabular}{|c|c|c|c|}
\hline Species & $\begin{array}{c}\text { Locality } \\
\text { (municipality/state) }\end{array}$ & $\begin{array}{c}\text { Number of } \\
\text { specimens analyzed }\end{array}$ & $\begin{array}{l}\text { Voucher number } \\
\text { in the CFBH Collection }\end{array}$ \\
\hline \multirow[t]{2}{*}{ Aplastodiscus perviridis A. Lutz and B. Lutz, 1950} & Poços de Caldas (MG) & $7(6 \mathrm{~m} ; 1 \mathrm{f})$ & $5840 ; 6987-6989 ; 7010-7012$ \\
\hline & São Bento do Sul (SC) & $5(\mathrm{~m})$ & $7406-7407 ; 5547-5549$ \\
\hline Aplastodiscus cochranae Mertens, 1952 & Rancho Queimado (SC) & $5(\mathrm{~m})$ & $6991 ; 7001 ; 7003-7005$ \\
\hline \multirow[t]{2}{*}{ Aplastodiscus albosignatus A. Lutz and B. Lutz, 1938} & Piraquara (PR) & $1(\mathrm{~m})$ & 5546 \\
\hline & São Bento do Sul (SC) & $5(\mathrm{~m})$ & $5543-5545 ; 6992-6993$ \\
\hline \multirow{2}{*}{ Aplastodiscus leucopygius Cruz and Peixoto, 1985} & Mogi das Cruzes (SP) & $7(\mathrm{~m})$ & $4012-4013 ; 6646-6647 ; 7391-7393$ \\
\hline & Maricá (RJ) & $2(\mathrm{~m})$ & $7395-7396$ \\
\hline \multirow[t]{3}{*}{ Hypsiboas albomarginatus Spix, 1824} & Bertioga (SP) & $5(\mathrm{~m})$ & $6406-6410$ \\
\hline & Picinguaba (SP) & $4(\mathrm{~m})$ & $7408-7410 ; 4011$ \\
\hline & Mogi das Cruzes (SP) & $2(\mathrm{~m})$ & $6403-6404$ \\
\hline \multirow[t]{2}{*}{ Hypsiboas faber Wied-Neuwied, 1821} & Mogi das Cruzes (SP) & $2(\mathrm{~m})$ & $4014 ; 6650$ \\
\hline & Biritiba Mirim (SP) & $1(\mathrm{~m})$ & 6982 \\
\hline
\end{tabular}

$\mathrm{CFBH}=$ Collection of the Department of Zoology of the State University of São Paulo (UNESP), Rio Claro, SP, Brazil. $\mathrm{f}=$ female, $\mathrm{m}=$ male.

Mitotic metaphases were obtained according to King and Rofe (1976) and Schimid (1978). The chromosomes were stained with $10 \%$ Giemsa in phosphate-buffered saline, $\mathrm{pH} 6.8$. C-banding and Ag-NOR (nucleolus organizer region) techniques were carried out according to Sumner (1972) and Howell and Black (1980), respectively. Ag-NOR locations were confirmed with fluorescent in situ hybridization (Viégas-Péquignot, 1992) using a 28S rDNA probe of the recombinant plasmid HM123, which contains a fragment of rDNA of Xenopus laevis (MeunierRotival et al., 1979). The preparations were examined using an Olympus BX60 light microscope. The chromosomes were classified according to Green and Sessions (1991).

\section{RESULTS}

All the specimens of A. cochranae, A. perviridis, H. albomarginatus, and H. faber had a diploid number of $2 \mathrm{n}=24$ chromosomes, whereas A. albosignatus had $2 \mathrm{n}=20$ and A. leucopygius, $2 \mathrm{n}=18$. The chromosomal morphology was similar in all of these species, with pairs $1,2,9,10,11$, and 12 being metacentric, and pairs $4,5,6$, and 7 being submetacentric. There 
was some variation in pair 3, which was metacentric in H. albomarginatus and submetacentric in the other species; similarly, pair 8 was submetacentric in A. albosignatus and A. leucopygius and metacentric in the other species (Figures $1 \mathrm{~A}-\mathrm{F}$ and $4 \mathrm{~A}-\mathrm{F}$, Table 2). Heterochromatin was detected in A. cochranae, A. perviridis and H. albomarginatus. Heterochromatin blocks were observed in the centromeric regions of all chromosomes, but differed in amount. In Aplastodiscus cochranae and A. perviridis, heterochromatic blocks were detected in the telomeric region of the short arms of pairs 1 and 2 and in the long arms of pairs 1 to 8 , as well as interstitially in the long arms of pairs $6,10,11$, and 12, and in the short arms of pair 11 of both species. Pair 12 had heterochromatin adjacent to the NOR (Figures 2A-C and 4A, B,E). In H. albomarginatus, positive C-bands were found in the telomeric regions of the short arms of pairs 1,2 and 3 and in the long arms of pairs 2 to 9 . Interstitial heterochromatin was seen in the short arms of pairs 2 to 4 and in the long arms of pairs 5 and 6 . On chromosome 2, the heterochromatin band coincided with the NOR and extended from this region to the centromere (Figures 2A-C and 4A,B,E).

The NOR occurred in the telomeric region of the long arm of pair 12 of $A$. cochranae and A. perviridis and of pair 9 of A. albosignatus and A. leucopygius. In H. albomarginatus, the NOR was located interstitially in the short arms of pair 2, and was heteromorphic for the homologous chromosomes. Hypsiboas faber had an NOR in the telomeric region of the long arm of pair 11 (Figures 3A-F and 4A-F). Secondary constrictions were frequently seen in some chromosomes of all species and were always associated with the NOR. In all species, the Ag-NOR coincided with the fluorescent in situ hybridization labeling obtained with the rDNA probe (Figure 3A-F). Table 3 summarizes the cytogenetic data for Aplastodiscus and the Hypsiboas species.

\begin{tabular}{|c|c|c|c|c|c|c|c|c|c|c|c|c|}
\hline & \multicolumn{12}{|c|}{ Chromosomes } \\
\hline & 1 & 2 & 3 & 4 & 5 & 6 & 7 & 8 & 9 & 10 & 11 & 12 \\
\hline \multicolumn{13}{|c|}{ A.perviridis } \\
\hline $\mathrm{RL} \%$ & 14.9 & 12.7 & 11.0 & 10.3 & 8.7 & 7.1 & 6.4 & 5.8 & 5.6 & 5.1 & 4.6 & 3.5 \\
\hline $\mathrm{CI}$ & 0.45 & 0.41 & 0.31 & 0.31 & 0.35 & 0.27 & 0.33 & 0.41 & 0.43 & 0.44 & 0.40 & 0.42 \\
\hline $\mathrm{CC}$ & M & M & SM & SM & SM & SM & SM & M & M & $\mathrm{M}$ & M & $\mathrm{M}$ \\
\hline \multicolumn{13}{|c|}{ A. cochranae } \\
\hline RL\% & 14.7 & 12.5 & 10.6 & 10.0 & 8.8 & 7.2 & 6.5 & 5.8 & 5.6 & 5.3 & 4.9 & 4.8 \\
\hline $\mathrm{CI}$ & 0.46 & 0.44 & 0.27 & 0.35 & 0.34 & 0.30 & 0.37 & 0.45 & 0.45 & 0.46 & 0.45 & 0.48 \\
\hline $\mathrm{CC}$ & M & $\mathrm{M}$ & $\mathrm{SM}$ & SM & SM & SM & SM & $\mathrm{M}$ & M & M & M & M \\
\hline \multicolumn{13}{|c|}{ A. albosignatus } \\
\hline RL\% & 15.9 & 13.0 & 11.3 & 10.9 & 10.3 & 10.0 & 8.7 & 6.6 & 4.9 & 2.2 & & \\
\hline $\mathrm{CI}$ & 0.46 & 0.41 & 0.33 & 0.31 & 0.29 & 0.29 & 0.29 & 0.27 & 0.40 & 0.45 & & \\
\hline $\mathrm{CC}$ & M & M & SM & SM & SM & SM & SM & SM & M & $\mathrm{M}$ & & \\
\hline \multicolumn{13}{|c|}{ A. leucopygius } \\
\hline RL\% & 17.9 & 13.9 & 11.5 & 11.2 & 10.9 & 10.2 & 8.6 & 6.4 & 2.9 & & & \\
\hline $\mathrm{CI}$ & 0.48 & 0.39 & 0.31 & 0.31 & 0.32 & 0.30 & 0.30 & 0.29 & 0.43 & & & \\
\hline $\mathrm{CC}$ & M & M & SM & SM & SM & SM & SM & SM & M & & & \\
\hline \multicolumn{13}{|c|}{ H. albomarginatus } \\
\hline RL\% & 15.3 & $\begin{array}{l}15.1 \\
13.2^{*}\end{array}$ & 11.7 & 10.5 & 9.3 & 8.3 & 6.6 & 5.8 & 5.5 & 5.1 & 4.1 & 3.6 \\
\hline $\mathrm{CI}$ & 0.48 & $\begin{array}{l}0.41 \\
0.40^{*}\end{array}$ & 0.41 & 0.33 & 0.30 & 0.28 & 0.40 & 0.41 & 0.44 & 0.47 & 0.44 & 0.46 \\
\hline & M & M & M & SM & SM & SM & $\mathrm{M}$ & M & M & M & $\mathrm{M}$ & $\mathrm{M}$ \\
\hline \multicolumn{13}{|l|}{ H. faber } \\
\hline $\mathrm{CI}$ & 0.45 & 0.41 & 0.30 & 0.34 & 0.35 & 0.28 & 0.32 & 0.46 & 0.42 & 0.44 & 0.40 & 0.44 \\
\hline $\mathrm{CC}$ & M & M & SM & SM & SM & SM & SM & $\mathrm{M}$ & $\mathrm{M}$ & $\mathrm{M}$ & $\mathrm{M}$ & $\mathrm{M}$ \\
\hline
\end{tabular}

$\mathrm{RL}=$ relative length; $\mathrm{CI}=$ centromeric index; $\mathrm{CC}=$ centromeric classification; $\mathrm{M}=$ metacentric; $\mathrm{SM}=$ submetacentric. (* = values for the morphs of chromosome 2 of $H$. albomarginatus). 


\section{A 8 ใ \\ В \\ C

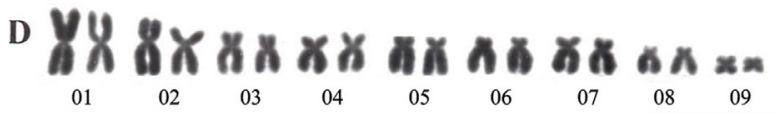 \\ E

\begin{tabular}{llllllllllll}
01 & 02 & 03 & 04 & 05 & 06 & 07 & 08 & 09 & 10 & 11 & 12 \\
\hline
\end{tabular}

F

Figure 1. Karyotypes of Aplastodiscus perviridis (A), A. cochranae (B), A. albosignatus (C), A. leucopygius (D), Hypsiboas albomarginatus $(\mathrm{E})$, and H. faber $(\mathrm{F})$. Arrows indicate the secondary constrictions. Bar $=10 \mu \mathrm{m}$.

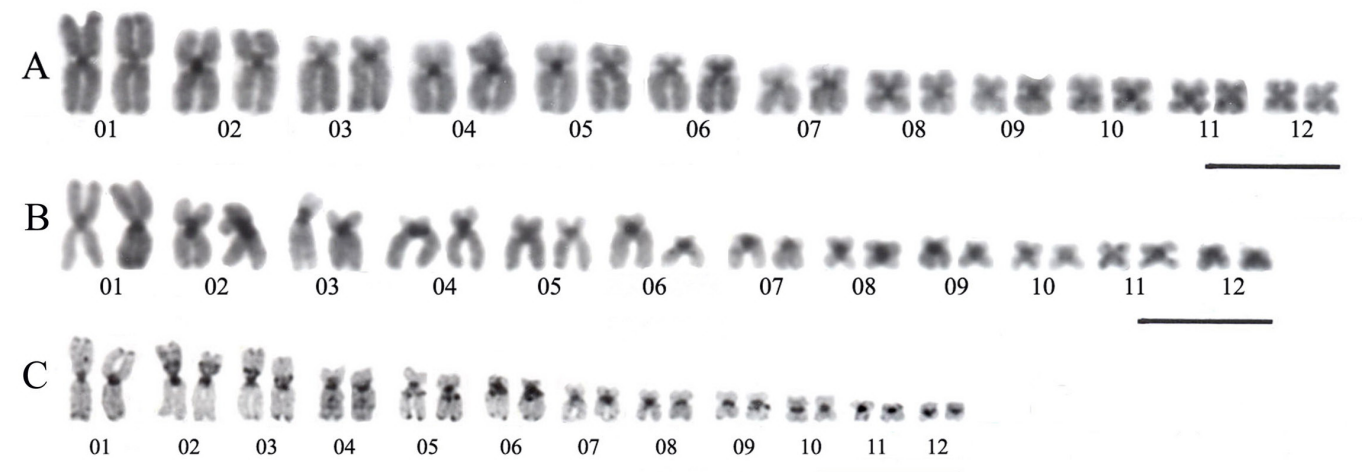

Figure 2. Karyotypes of Aplastodiscus perviridis (A), A. cochranae (B) and Hypsiboas albomarginatus (C) stained by $\mathrm{C}$-banding. Arrows indicate interstitial and telomeric bands. Bar $=10 \mu \mathrm{m}$. 


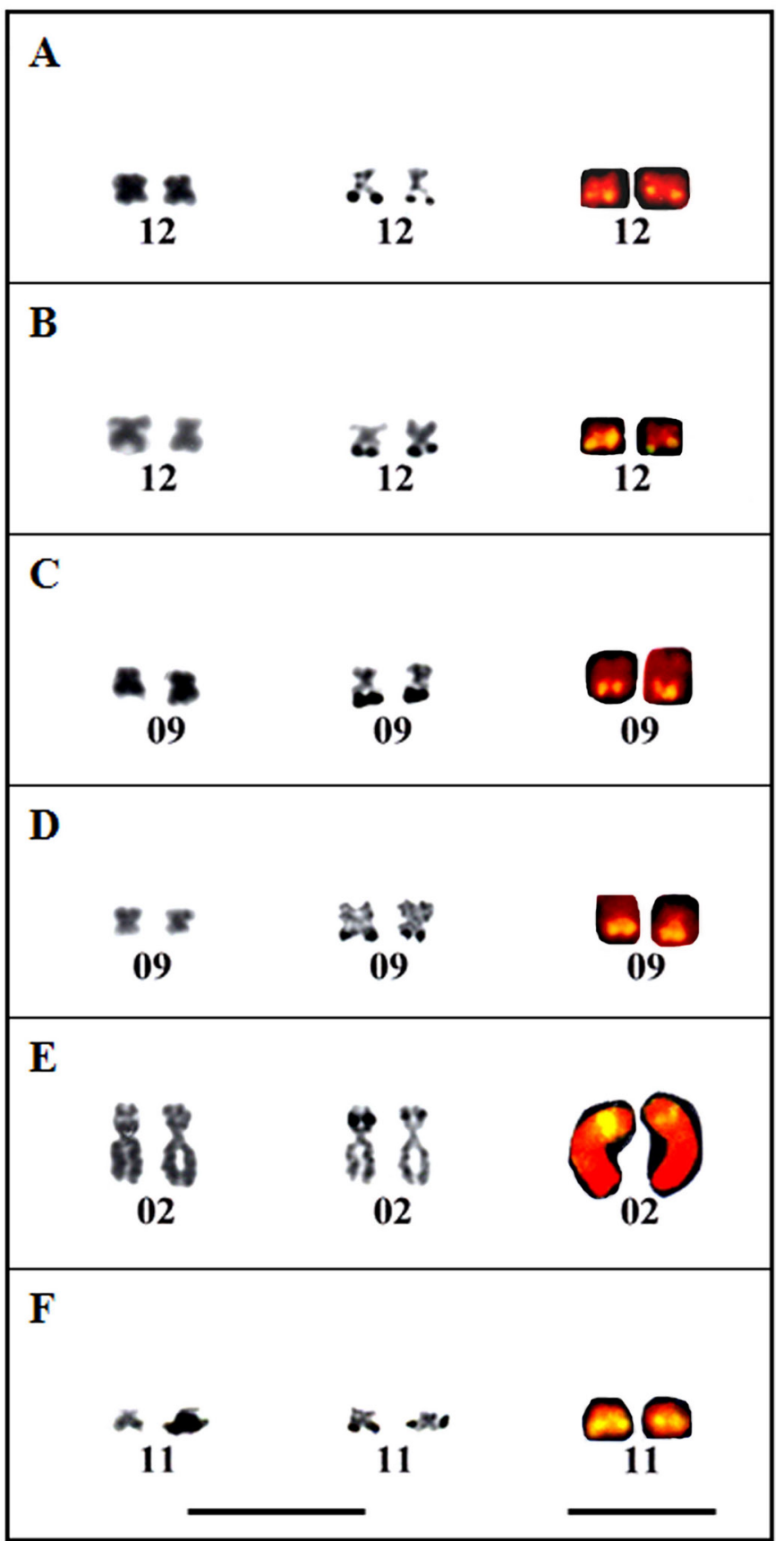

Figure 3. Chromosomal pairs containing the NOR region, as detected by Giemsa staining, silver staining and in situ hybridization with rDNA probe. Aplastodiscus perviridis (A), A. cochranae (B), A. albosignatus (C), A. leucopygius (D), Hypsiboas albomarginatus (E), and H. faber (F). Bar $=10 \mu \mathrm{m}$. 
$\mathbf{A}$

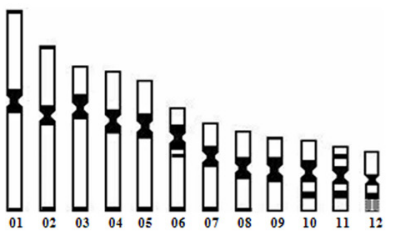

C

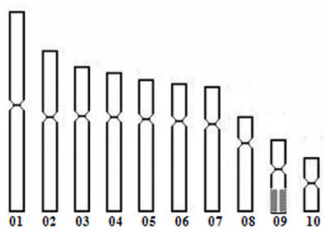

$\mathbf{E}$

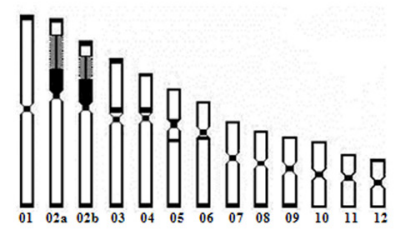

B

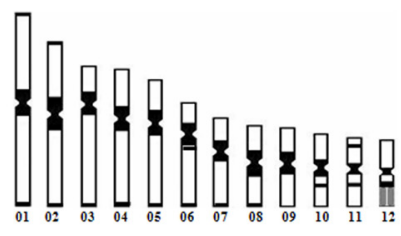

D

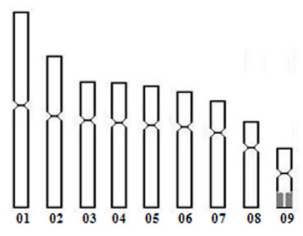

$\mathbf{F}$

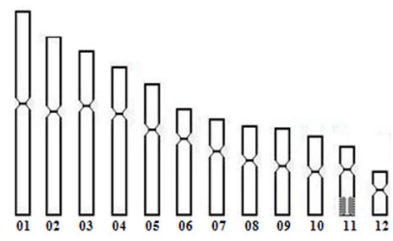

Figure 4. Ideograms of the karyotypes of Aplastodiscus perviridis (A), A. cochranae (B), A. albosignatus (C), A. leucopygius (D), Hypsiboas albomarginatus (E), and H. faber (F). The black blocks indicate $\mathrm{C}$ bands and the gray areas show the NOR. The hatched regions are the secondary constrictions. In $E$, the letters $a$ and $b$ indicate the morphs of chromosome 2 .

\begin{tabular}{|c|c|c|c|c|c|c|}
\hline \multirow[t]{2}{*}{ Old taxon } & \multirow[t]{2}{*}{$\begin{array}{l}\text { Current taxon (sensu } \\
\text { Faivovich et al., 2005) }\end{array}$} & \multirow[t]{2}{*}{$2 \mathrm{n}$} & \multirow[t]{2}{*}{$\begin{array}{l}\text { Chromosomal } \\
\text { morphology }\end{array}$} & \multirow[t]{2}{*}{$\begin{array}{l}\text { NOR-bearing } \\
\text { pair }\end{array}$} & \multicolumn{2}{|c|}{$\begin{array}{c}\text { Heterochromatin } \\
\text { (non-centromeric C-bands) }\end{array}$} \\
\hline & & & & & Interstitial & Pericentromeric \\
\hline $\begin{array}{l}\text { Aplastodiscus } \\
\text { perviridis }\end{array}$ & $\begin{array}{l}\text { Aplastodiscus } \\
\text { perviridis }\end{array}$ & 24 & $\begin{array}{l}\text { M; M; SM; SM; SM; } \\
\text { SM; SM; M; M; M; M; M }\end{array}$ & $12 q 12 q$ & $11 p, 11 q$ and $10 q$ & pair 6 \\
\hline $\begin{array}{l}\text { Aplastodiscus } \\
\text { cochranae }\end{array}$ & $\begin{array}{l}\text { Aplastodiscus } \\
\text { cochranae }\end{array}$ & 24 & $\begin{array}{l}\text { M; M; SM; SM; SM; SM; } \\
\text { SM; M; M; M; M; M }\end{array}$ & $12 q 12 q$ & $11 \mathrm{p}$ and $10 \mathrm{q}$ & pair 6 \\
\hline $\begin{array}{l}\text { Hyla } \\
\text { albomarginata }\end{array}$ & $\begin{array}{l}\text { Hypsiboas } \\
\text { albomarginatus }\end{array}$ & 24 & $\begin{array}{l}\mathrm{M} ; \mathrm{M} ; \mathrm{M} ; \mathrm{SM} ; \mathrm{SM} ; \mathrm{SM} \\
\mathrm{M} ; \mathrm{M} ; \mathrm{M} ; \mathrm{M} ; \mathrm{M} ; \mathrm{M}\end{array}$ & $2 \mathrm{p} 2 \mathrm{p}$ & $\begin{array}{l}2 \mathrm{p}, 3 \mathrm{p}, 4 \mathrm{p} \text { and } \\
5 \mathrm{q}, 6 \mathrm{q}\end{array}$ & pair 2 \\
\hline Hyla faber & Hypsiboas faber & 24 & $\begin{array}{l}\text { M; M; SM; SM; SM; SM; } \\
\text { SM; M; M; M; M; M }\end{array}$ & $11 \mathrm{q} 11 \mathrm{q}$ & - & - \\
\hline $\begin{array}{l}\text { Hyla } \\
\text { albosignata }\end{array}$ & $\begin{array}{l}\text { Aplastodiscus } \\
\text { albosignatus }\end{array}$ & 20 & $\begin{array}{l}\text { M; M; SM; SM; SM; SM; } \\
\text { SM; SM; M; M }\end{array}$ & $9 q 9 q$ & - & - \\
\hline $\begin{array}{l}\text { Hyla } \\
\text { leucopygia }\end{array}$ & $\begin{array}{l}\text { Aplastodiscus } \\
\text { leucopygius }\end{array}$ & 18 & $\begin{array}{l}\text { M; M; SM; SM; SM; SM; } \\
\text { SM; SM; M }\end{array}$ & $9 \mathrm{q} 9 \mathrm{q}$ & - & - \\
\hline
\end{tabular}

$\mathrm{p}=$ short arm; $\mathrm{q}=$ long arm. 


\section{DISCUSSION}

The analysis of chromosomal number and morphology has been useful for differentiating some frog species that have a similar external morphology, e.g., Megaelosia spp (Giaretta and Aguiar-Jr, 1998; Rosa et al., 2003), Dendropsophus nanus and D. sanborni (as Hyla in Medeiros et al., 2003) and Colostethus (Veiga-Menoncello et al., 2003). As shown here, the karyotypes of $A$. cochranae and A. perviridis had the same diploid number of 24 chromosomes and a conserved chromosomal morphology. This characteristic is frequent in the Hylidae, as reported for closely related species such as H. marginatus, H. semiguttatus and Hypsiboas sp (aff. H. semiguttatus) (Ananias et al., 2004), H. bischoffi and H. guentheri (Raber et al., 2004), H. polytenius and H. leptolineatus (Vieira, 2004). However, in these species, the karyotypes could be distinguished by the NOR location and/or heterochromatin pattern. In contrast, in addition to having the same chromosomal number and morphology shown here, the NOR location and heterochromatin pattern were also identical in A. cochranae and A. perviridis, making it impossible to distinguish these two species based solely on their cytogenetic characteristics.

Although the two species of the A. albosignatus group, A. albosignatus and A. leucopygius, differed in their chromosomal number $(2 \mathrm{n}=20$ and 18 , respectively), their chromosomal morphology was very similar. The difference in chromosomal number apparently resulted from the loss of a small metacentric chromosome, probably chromosome 10, since chromosome pair 9 in the two species had almost the same size and had the NOR in the same position. Other chromosomes in these species were also morphologically very similar. The results for A. albosignatus differed from those reported by Bogart (1973), who analyzed two other populations assigned to this species, i.e., Boracéia, SP, with $2 \mathrm{n}=20$ and Teresópolis, RJ, with $2 \mathrm{n}=18$ chromosomes. The karyotype with $2 \mathrm{n}=18$ chromosomes found by Bogart is identical to that of $A$. leucopygius analyzed here and collected from a region (Maricá) very close ( $\sim 50 \mathrm{~km})$ to Teresópolis. Since A. leucopygius from the same locality (Teresópolis, RJ) was described by Cruz and Peixoto (1984), the cytogenetic data suggest that the species studied by Bogart (1973) was, in fact, A. leucopygius and not A. albosignatus.

The karyotypes of $A$. albosignatus $(2 \mathrm{n}=20)$ and A. leucopygius $(2 \mathrm{n}=18)$ were also similar to that of $A$. cochranae and A. perviridis $(2 \mathrm{n}=24)$. The difference between these species appears to have resulted from a reduction in the number of chromosomes, since similar karyotypes, with $2 \mathrm{n}=24$, occur in other Hylinae species. This reduction involves mainly the smaller chromosomes, since the first seven chromosomes are highly conserved in size and morphology. Also, the NOR-bearing chromosome 9 in A. albosignatus and A. leucopygius is very similar in size, morphology (metacentric) and NOR location (telomeric region) to pair 12 of $A$. cochranae and $A$. perviridis. A reduction in chromosome number has also been used to explain similar karyotypic variations in other anurans (Beçak, 1968; Bogart, 1970; Veiga-Menoncello et al., 2003; Siqueira-Jr. et al., 2004; Gruber et al., 2007). Although the chromosomal morphology of $H$. albomarginatus was very similar to that of the other species studied here, the location of the NOR on the large chromosome pair 2 differentiated this species from the others.

The NOR heteromorphism seen in the homologous chromosomes of pair 2 in H. albomarginatus is rather common in anurans and probably resulted from the amplification of rDNA sequences, which could explain the small increase in total length of the larger NOR-bearing chromosome.

The molecular data reported by Faivovich et al. (2005) showed that H. albomarginatus (previously Hyla albormarginata) was more closely related to other Hylinae species and was 
included in the H. faber group, whereas A. albosignatus and A. leucopygius (previously Hyla albosignata and Hyla leucopygia of the Hyla albormarginata group) were related to Aplastodiscus. Both genera are in the same monophyletic tribe within the Hylinae. The karyotype and the NOR-bearing chromosomal pair in $H$. faber are very similar to those of $A$. perviridis and $A$. cochranae, suggesting a close relationship, whereas in $H$. albomarginatus, the NOR location (pair 2) and the heterochromatin pattern are very distinct. The NOR in pair $11 \mathrm{of} H$. faber also occurs at the same site in $H$. raniceps ( $H$. albopunctata group), whereas in $H$. crepitans $(H$. faber group) (Gruber et al., 2007) the NOR occurs at a site located interstitially. These findings suggest that the NOR sites and heterochromatin dispersion have been involved in the chromosomal evolution of this group.

The cytogenetic data obtained so far indicate that the species of Aplastodiscus and the $H$. faber group are very closely related and may have originated from a common ancestor. The chromosomal differentiation of the species analyzed here appears to have occurred by a reduction in the chromosome number (from $2 \mathrm{n}=24$ to $2 \mathrm{n}=20$ and $2 \mathrm{n}=18$ ), as already postulated by Gruber et al. (2007) to explain the reduction from $2 n=24$ to $2 n=22$ in H. albopunctatus, as well as by rearrangements involving mainly the smaller chromosomes (including the NORbearing ones). The latter conclusion is supported by the finding that the size and morphology of the first seven chromosomes are highly conserved in both genera.

\section{ACKNOWLEDGMENTS}

The authors thank Denise Maria Peccinini-Seale (deceased), Marilia T. Hartmann, Fernando Ananias, Sérgio Siqueira Junior, Samantha Celi Vieira, and Marcos Yamamoto for collecting some of the specimens. Research supported by the Brazilian agencies Fundação de Amparo à Pesquisa do Estado de São Paulo (FAPESP, grant \#04/10901-6) to S.M. Recco-Pimentel and Conselho Nacional de Desenvolvimento Científico e Tecnológico (CNPq, grant \#481124/2004-7).

\section{REFERENCES}

Ananias F, Garcia PC and Recco-Pimentel SM (2004). Conserved karyotypes in the Hyla pulchella species group (Anura, Hylidae). Hereditas 140: 42-48.

Beçak ML (1968). Chromosomal analysis of eighteen species of Anura. Caryologia 21: 191-208.

Bogart JP (1970). Systematic problems in the amphibian family Leptodactylidae (Anura) as indicated by karyotypic analysis. Cytogenetics 9: 369-383.

Bogart JP (1973). Evolution of Anuran Karyotypes. In: Evolutionary Biology of Anurans (Vial JL, ed.). University of Missouri Press, Columbia, 337-349.

Bokermann WCA (1966). Lista Anotada das Localidades tipo de Anfíbios Brasileiros. Serviço de Documentação - USP, São Paulo.

Bokermann WCA (1967). Notas sobre cantos nupciais de anfíbios brasileiros. I (Anura). An. Acad. Bras. Cienc. 39: 441-443.

Bokermann WCA and Sazima I (1973). Anfíbios da Serra do Cipó, Minas Gerais, Brasil. 1: Duas espécies novas de Hyla (Anura, Hylidae). Rev. Bras. Biol. 33: 457-472.

Cardoso AJ and Haddad CFB (1992). Diversidade e turno de vocalizações de anuros em comunidade neotropical. Acta Zool. Lilloana 41: 93-105.

Cardoso AJ, Andrade GV and Haddad CFB (1989). Distribuição espacial em comunidades de anfíbios (Anura) no sudeste do Brasil. Rev. Bras. Biol. 49: 241-249.

Carvalho e Silva APT and Carvalho e Silva SP (2005). New species of the Hyla albofrenata group, from the States of Rio de Janeiro and São Paulo, Brazil (Anura, Hylidae). J. Herpetol. 39: 73-81.

Cei JM (1980). Amphibians of Argentina. Monitore Zool. Italiano (Nuova Serie) 2: XII+609. 
Cei JM and Roig VG (1961). Batracios recolectados por la Expedición Biológica "Erspamer" a la mesopotamia argentina y selva oriental de Misiones. Notas Biol. Fac. Cienc. Exactas, Fis. Nat., Nordeste Corrientes, Zool. 1: 5-40.

Cruz CAG and Peixoto AL (1984). Espécies verdes de Hyla: o complexo “Albosignata” (Amphibia, Anura, Hylidae). Arq. Univ. Fed. Rur. Rio de Janeiro 7: 31-47.

Cruz CAG and Peixoto AL (1985). Espécies verdes de Hyla: o complexo "albofrenata” (Amphibia, Anura, Hylidae). Arq. Univ. Fed. Rur. Rio de Janeiro 8: 59-70.

Cruz CAG, Pimenta BVS and Silvano DL (2003). Duas novas espécies pertencentes ao complexo de Hyla albosignata Lutz and Lutz, 1938, do leste do Brasil (Amphibia, Anura, Hylidae). Bol. Mus. Nac., N. S., Zool. 503: 1-13.

Duellman WE (1977). Liste der rezenten Amphibien und Reptilien: Hylidae, Centrolenidae, Pseudidae (Das Tierreich). de Gruyter, Berlin, New York.

Faivovich J, Haddad CFB, Garcia PCA, Frost DR, et al. (2005). Systematic review of the frog family Hylidae, with special reference to the Hylinae: phylogenetic analysis and taxonomic revision. Bull. Am. Mus. Nat. Hist. 294: 1-240.

Frost DR (1985). Amphibian Species of the World. Association of Systematics Collections and Allen Press, Lawrence, $110-203$.

Frost DR (2009). Amphibian Species of the World, an Online Reference. Version 5.3. American Museum of Natural History, New York. Available at [http://research.amnh.org/herpetology/amphibia/index.html]. Accessed February $12,2009$.

Garcia PCA, Caramaschi U and Kwet A (2001). The taxonomic status of the Hyla cochranae Mertens and recharacterization of Aplastodiscus A. Lutz (Anura, Hylidae). [O status taxonômico de Hyla cochranae Mertens e recaracterização de Aplastodiscus A. Lutz (Anura, Hylidae)]. Rev. Bras. Zool. 18: 1197-1218.

Giaretta AA and Aguiar O Jr (1998). A new species of Megaelosia from the Mantiqueira Range, Southeastern Brazil. J. Herpetol. 32: 80-83.

Green MD and Sessions SK (1991). Nomenclature for Chromosomes. In: Amphibian Cytogenetics and Evolution (Green MD and Sessions SK, eds.). Academic Press, San Diego, 431-432.

Gruber SL, Haddad CF and Kasahara S (2007). Chromosome banding in three species of Hypsiboas (Hylidae, Hylinae), with special reference to a new case of B-chromosome in anuran frogs and to the reduction of the diploid number of $2 \mathrm{n}=24$ to $2 \mathrm{n}=22$ in the genus. Genetica $130: 281-291$.

Haddad CFB, Faivovich J and Garcia PCA (2005). The specialized reproductive mode of the tree frog Aplastodiscus perviridis (Anura: Hylidae). Amphibia-Reptilia 26: 87-92.

Howell WM and Black DA (1980). Controlled silver-staining of nucleolus organizer regions with a protective colloidal developer: a 1-step method. Experientia 36: 1014-1015.

King M and Rofe R (1976). Karyotypic variation in the Australian gekko Phyllodactylus marmoratus (Gray) (Gekkonidae: Reptilia). Chromosoma 54: 75-87.

Lavilla EC (1992). Tipos portadores de nombre y localidades tipos de anfíbios de Argentina. Acta Zool. Lilloana 42 : 1-7.

Lutz B (1949). Anfibios anuros da coleção Adolpho Lutz II. Espécies verdes do gênero Hyla do leste meridional do Brasil. Mem. Inst. Oswaldo Cruz 46: 551-577.

Lutz B (1950). Hylidae in the Adolpho Lutz collection of the Instituto Oswaldo Cruz: V. Mode of locomotion and structure of hand and foot; Va. Phyllomedusa (Pithecopus) burmeisteri distincta A. Lutz: Vb. Aplastodiscus perviridis A. Lutz [Anfibios Anuros da coleção Adolpho Lutz: V. locomoção e estrutura das extremidades Va. Phyllomedusa (P.) burmeisteri distincta A. lutz: Vb. Aplastodiscus perviridis A. Lutz]. Mem. Inst. Oswaldo Cruz 48: 599-637.

Lutz B (1973). Brazilian Species of Hyla. University of Texas Press, Austin.

Lutz A and Lutz B (1950). Anfíbios anuros da coleção Adolpho Lutz do Instituto Oswaldo Cruz. Mem. Inst. Oswaldo Cruz 48: 612-637.

Medeiros LR, Rossa-Feres DC and Recco-Pimentel SM (2003). Chromosomal differentiation of Hyla nana and Hyla sanborni (Anura, Hylidae) with a description of NOR polymorphism in H. nana. J. Hered. 94: 149-154.

Mertens R (1952). Eine neue Hyla aus Santa Catharina, Brasilien. Senckenbergiana 33: 165-167.

Meunier-Rotival M, Cortadas J, Macaya G and Bernardi G (1979). Isolation and organization of calf ribosomal DNA. Nucleic Acids Res. 6: 2109-2123.

Raber SC, Carvalho KA, Garcia PCA, Vinciprova G, et al. (2004). Chromosomal characterization of Hyla bischoffi bischoffi and Hyla guentheri (Anura, Hylidae). Phyllomedusa 3: 43-49.

Rosa C, Aguiar-Jr O, Giaretta AA and Recco-Pimentel SM (2003). Karyotypic variation in the genus Megaelosia (Anura, Hylodinae) with the first description of a B-chromosome in a leptodactylid frog. Copeia 1: 166-174.

Schimid M (1978). Chromosome banding in Amphibia. I. Constitutive heterochromatin and nucleolus organizer regions in Bufo and Hyla. Chromosoma 66: 361-388.

Silva HR (1998). Phylogenetic Relationships of the Family Hylidae with Emphasis on the Relationships within the Subfamily Hylinae (Amphibia: Anura). Doctoral thesis, Museu Nacional do Rio de Janeiro, Universidade do Rio de 
Janeiro, Rio de Janeiro.

Siqueira-Jr S, Ananias F and Recco-Pimentel SM (2004). Cytogenetics of three Brazilian species of Eleutherodactylus (Anura, Leptodactylidae) with 22 chromosomes and re-analysis of multiple translocations in E. binotatus. Genet. Mol. Biol. 27: 363-372.

Sumner AT (1972). A simple technique for demonstrating centromeric heterochromatin. Exp. Cell Res. 75: 304-306.

Veiga-Menoncello ACP, Lima AP and Recco-Pimentel SM (2003). Cytogenetic analysis of four central Amazonian species of Colostethus (Anura - Dendrobatidae) with a diploid complement of 22 chromosomes. Hereditas 139: 189-198.

Viégas-Péquignot E (1992). In situ Hybridization to Chromosomes with Biotinylated Probes. In: In situ Hybridization: a Practical Approach (Willernson D, ed.). Oxford University Press-IRL Press, Oxford, 137-158.

Vieira SC (2004). Caracterização Cromossômica de Espécies do Grupo de Hyla polytaenia (Anura, Hylidae). Master's dissertation, Instituto de Biologia, Universidade Estadual de Campinas, Campinas. 